DOI: 10.20472/IAC.2020.054.010

\author{
OMAR ESPARZA \\ Arizona State University, United States
}

\title{
IN PRAISE OF HOPELESSNESS: GROUNDWORK FOR AN ETHICS OF THE DEAD
}

\begin{abstract}
:
Posthumanism is often associated with a relatively recent historical movement encompassing many fields, including science-fiction, sociology, philosophy, architecture, and other forms of art. Though it comes in many flavors, posthumanism is broadly defined as a late-capitalist critique of Western humanism. Characterizing posthumanism (and humanism) in this way is not wrong, but it is limited precisely by the late-capitalist framework posthumanism wishes to reject. If posthumanism is entangled in Eurocentrism, then it preserves humanism, including its most noxious elements: property, rights, anthropocentrism, democracy, onto-political hierarchy, etc., all of which have in one way or another contributed to the current climate crisis. This investigation reimagines posthumanism unencumbered by Eurocentrism to establish an ecological system of ethics that embraces the end of humanity, which has always already arrived. Part one of this investigation proposes to do two things: A) to show that posthumanism is not one historical moment, but the precondition for every possible experience; and B) to organize these posthumanists based on their most common concern, how unstable they think the categories human and non-human are. I conclude part one by arguing that posthumanism properly conceived forces one to conclude that to be human is always to be posthuman. Part two lays the groundwork for ethics of the dead. I critique the idea of hope prevalent in all ethical systems. As an alternative for "solving" the climate crisis, I propose that posthumanism properly understood provides the only sound ethical basis for restructuring a species coming to terms with its deadness: hopelessness.
\end{abstract}

\section{Keywords:}

Posthumanism, Speculative Realism, Ecocriticism, Climate Change, Transcendental Nihilism, Flat Ontology

JEL Classification: 039, Z19 